Прегледни чланак

Zoltán B Nagy, Ph.D., Associate Professor

University of Miskolc

Faculty of Law

jogdrnz@uni-miskolc.hu

Anett S Csiszár, lawyer

anett.csiszar92@gmail.com

\title{
ASPECTS OF THE EUROPEAN SYSTEM OF FINANCIAL SUPERVISION*
}

Abstract: The study presents the main stages of the development of the European financial supervisory regulation and the current European System of Financial Supervision. The financial economic crisis highlighted the weaknesses in the supervisory system and the fact that the supervisor has an important role in consumer protection and in the mitigation of risk-taking by financial institutions. The European Union has developed a new financial strategy known as Banking Union, which has a three-pillar framework. These three pillars are the Single Supervisory Mechanism, the Single Resolution Mechanism and the Common Deposit Guarantee Scheme. This system is intended to achieve a single economic and monetary union at supranational level and to avoid the emergence of a new crisis as far as possible.

Keywords: Banking Union, financial supervision, SSM, SRM, DGS, European Central Bank, European System of Financial Supervision, banking regulation.

\section{INTRODUCTION}

The establishment of an effective financial supervision system has been an important task as it had been shown by the recent financial economic crisis. The beginning of the crisis ${ }^{1}$ was in 2007, and in 2008 it got to the European countries

\footnotetext{
* This research was partially carried out in the framework of the Center of Excellence of Mechatronics and Logistics at the University of Miskolc.

${ }^{1}$ Đorđe Popov, Svetska ekonomska kriza i restrukturiranje dugova, Zbornik radova Pravnog fakulteta u Novom Sadu 1/2009, p. 7-20.
} 
bringing along sweeping changes in the regulation of the subject, not only on domestic level, but also in the European Union and even all over the world. ${ }^{2}$ Prior to these alterations there were shortcomings in the regulation of the financial system and supervision that played an important role in the over-indebtedness of the households and in the spread of the foreign currency loans in several Eastern European countries. ${ }^{3}$

As the crisis unravelled, the liberal, permissive legislation failed to remain sustainable stability in the financial markets. The financial intermediary system is insomuch a key element of the states and their economies that its orderly operation is a social interest. ${ }^{4}$ This serves as proof of state intervention, under which the State can build up a proper "defense" system.

The financial supervision as a subject matter of this article can be considered timely and up to date, not only for the reasons we have indicated above, but also due to the overall reform of the legislation that took place a few years ago, and the practice resulting from the new provisions is only now emerging.

Financial supervision means the supervision of financial institutions by a public body responsible for monitoring the areas defined by the public interest. ${ }^{5}$ To put it more simply, it refers to an activity, a process by which the purpose is to obtain assurance that something was carried out properly, correctly. ${ }^{6}$ Of course, not only government agencies carry out financial supervision, nowadays supervision performed by the central banks is increasingly gaining ground.

The purpose of supervision is, regardless of the institutional form, to maintain the effectiveness of the existing regulation in the financial sector and the stability of the financial system (financial institutions and financial markets). Financial stability is a condition in which the financial system - financial markets and financial institutions - is resistant to shocks affecting the economy and the ability to seamlessly fulfil the basic functions. ${ }^{8}$ And this can be achieved if the risks are recognized in time and handled accordingly.

${ }^{2}$ Đorđe Popov, Svetska ekonomska kriza i Srbija, Zbornik radova Pravnog fakulteta u Novom Sadu 3/2010, p. 7-26.

${ }^{3}$ Az MNB pénzügyi felügyeleti funkcióinak megerösítése, http://www3.mnb.hu/letoltes/ felugyelet-hu.pdf, accessed 14.02.2016.

${ }^{4}$ Nagy Zoltán: A gazdasági válság hatása a pénzügyi intézmények és szolgáltatások szabályozására, p. 230., Miskolc University Press, Sectio Juridica et Politica, Tomus XXVIII.,2010.

${ }^{5}$ Investor Dictionary: Definition of financial supervision,

http://www.investordictionary.com/definition/financial-supervision, accessed 06.02. 2016.

${ }^{6}$ Financial Times: Definition of supervision,

http://lexicon.ft.com/Term?term=supervision, accessed 13.02. 2016.

${ }^{7}$ Investor Dictionary: Definition of financial supervision, ibid.

${ }^{8}$ Dr. Kálmán János: A pénzügyi stabilitás „háromlábú széke“ - különös tekintettel az Európai Bankunió koncepciójára, SZE-ÁJDI, TAMOP 4.2.2b Pályázat könyve, 
Supervision can be characterized as a sort of an executive power appearing in the financial system. The supervising agencies are related to the legislative power as well: they are subordinate to the legislation produced by the legislature - which can optionally be the government or the parliament. In addition, the supervisors themselves are endowed with certain legislative powers which are defined by each state. ${ }^{9}$

Crockett ${ }^{10}$, for example, describes supervisors as accessories to the financial system's infrastructure. This is the "infrastructure" on which the financial systems can rely for proper operation that involves contract law, enforcement law, auditing activities, prudential rules and effective supervision, appropriate disclosure requirements and the creation of well-functioning payment and settlement systems. When establishing the regulatory framework, the optimal allocation of responsibility is of key importance to ensure that the financial system can operate efficiently and effectively. ${ }^{11}$

According to Zsolnai, the essence of the supervisory activity is that the presumption of innocence must be strictly maintain, alongside with analysing, interpreting and checking everything in a rational manner. ${ }^{12}$

If we continue to investigate the supervision, we can determine it as a protective equipment of society. This approach leads to the raison d'etre of supervision, as it needs to protect society and the community from financial instability. In Farkas' view society is paying the supervision's operation in exchange for protection from a "greater harm" including the social costs resulting from it.

But from what exactly ought to protect the supervisor? This can be ascertained mainly from the objectives set by the law concerning the supervision, however, there are generally identifiable objectives too that will always be valid. This happens where the legitimate interests of the market operators need protection, while on the other side consumers as well as the market have to be protected to

http://www.tankonyvtar.hu/hu/tartalom/tamop422b/2010-0010_kotet_02_penzugyi_stabilitas_haromlabu_szeke_kalman_janos/penzugyi_stabilitas_haromlabu_szeke_kalman_janos_1_1. html, accessed 6.02. 2016.

${ }^{9}$ Andreas Grünbichler and Patrick Darlap: Regulation and Supervision of Financial Markets and Institutions, A European Perspective, July 2003,

http://www.fep.up.pt/disciplinas/pgaf924/PGAF/Texto_7_Grunbichler_Darlap.pdf, accessed 06.02. 2016.

${ }^{10}$ Crockett, Andrew: Central banking, financial stability and Basel II. Speech at the 38th SEACEN Governors' Conference, Manila, 13 February 2003., http://www.bis.org/speeches/ sp030213.htm, accessed 07.02. 2016.

${ }^{11}$ Andreas Grünbichler and Patrick Darlap: ibid.

12 Zsolnai Alíz: A pénzügyi szektorbeli felügyelet kérdései az Európai Unió tükrében, Hitelintézeti Szemle, 2009/5. Lentner Csaba:A magyar gazdasági válság és válságkezelés néhány történeti és nemzetközi aspektusa,Pénzügyi Szemel,201063. p. 561-585. 
ensure fair competition. The negative effects of the financial crisis constitute further part of protection, and the maintenance of confidence in the financial system and the fight against financial abuses and financial crime can be mentioned as well. ${ }^{13}$

The responsibility of the supervisors is moreover to strengthen market discipline, plus constantly endeavor to get a solution to the banks that are in trouble and to the banking system's problems. These requirements can only be fulfilled if the flow of information, transparency, cooperation between the authorities, the uniformity of the financial reporting system, and the accessibility of information relating to the activities of supervisors are being developed in the banking system. ${ }^{14}$

Who claim that financial supervision is not required, most often explain it by the fact that the financial markets function well, market distortions cannot or only in exceptional circumstances can occur, thus it does not justify maintaining a supervisor, it is not worth the "costs ".

However, the necessity is substantially supported by a greater number of factors. If we think about the banks, they carry the risk of "hazardous operation" in nature, since they handle payments, play an important role in the economy, problems related to their activities thereby affect the financial system. Further criteria may be laid down in connection with the clients. Clients are generally not in possession of proper information, the supervisory body can easily make accessible and available to them all the information on individual financial institutions and financial products without having to obtain the information they need for themselves. It would certainly be much more difficult if it was their task. The supervision also provides the basis of protection of consumers' interest because data and information provided by financial institutions can flow through it so that clients can be prevented from abuses and scams. Transactions on financial products require greater foresight as they are different from the rest of the industries' products.

We believe that in the modern financial system financial supervision is indispensable, but the operation should be linked with the accountability requirements in any case. The supervisors always have to report their activities to the National Assembly on the one hand, and to society on the other hand. It may meet through written or oral report, supplemented by the possibility of having recourse to various media channels. Thus, they make sure that the supervisors

${ }^{13}$ Farkas István: Pénzügyi felügyeletek működési alapja, a Pénzügyi Szervezetek Állami Felügyeletének Stratégiája p. 429., In Dr. Lentner Csaba (szerk.): Pénzügypolitikai stratégiák a XXI. század elején, Akadémiai Kiadó, Budapest, 2007. Lentner Csaba:Közpénzügyek és államháztartástan,Nemzeti Közszolgálati és Tankönyvkiadó,Budapest,2013.,p.280-330.

${ }^{14}$ Ligeti Sándor: A pénzügyi felügyeletek függetlensége és beszámoltathatósága. A határokon átnyúló pénzügyi tevékenység felügyelete, p. 70., Külgazdaság, LIII. évf., 2009. jan.-febr. 
carry out their activities in accordance with the law and if they do not, they may be contested before court on unlawful measures. ${ }^{15}$

\section{THE DEVELOPMENT OF THE REGULATION OF FINANCIAL SUPERVISION IN THE EUROPEAN UNION}

The main steps of the regulation need to be reviewed in order to understand the current situation, even if the presentation of the complete development history, because of space limitations, is not possible within the framework of this study.

The financial sector had a special significance in Brussels since the mid1980s. The Commission initially was in favour of detailed harmonization directives, the first banking coordination directive ${ }^{16}$ adopted in 1977 exemplifies this tendency. The turning-point was the White Paper ${ }^{17}$ in 1985. The focus shifted gradually away from detailed harmonization towards mutual recognition between Member States. The liberalization of financial services were placed high in the White Paper but the most important goal was all along to build the single market. In the Commission's policy a new element came to the fore, namely the protection of consumers. The economic and monetary integration, technological process, and the recognition that changes are necessary to complete the single market led to the Financial Services Action Plan ${ }^{18}$ and the related Lamfalussy procedure. The Financial Services Action Plan contained three main objectives, the most relevant of these is ensuring uniform standards of supervision of financial markets in the Member States and at EU level as well that can be achieved through harmonization of the laws and closer cooperation between the Member States' authorities. ${ }^{19}$ The financial supervisory and prudential regulations should be developed further, the stability of the European financial markets must be preserved. The Action Plan came true at the beginning of 2005, the Lamfalussy method was expanded from the capital market to the banking and insurance sectors. ${ }^{20}$ p.63- 67.

${ }^{15}$ Ligeti Sándor: A pénzügyi felügyeletek függetlensége és beszámoltathatósága., op. cit.

${ }^{16}$ Council Directive 77/780/EEC on the coordination of laws, regulations, and administrative provisions relating to the taking up and pursuit of the business of credit institutions, OJ L 332, 1977. 12.17.

${ }^{17}$ Completing the Internal Market. White Paper from the Commission to the European Council, COM (85) 310 final, 14 June 1985

${ }^{18}$ Commission Communication of 11 May 1999 entitled „Implementing the framework for financial markets: action plan" [COM (1999) 232 final]

${ }^{19}$ Kende Tamás - Széles Tamás: Bevezetés az Európai Unió politikáiba, p. 469-472., Complex Kiadó, Budapest, 2011.

${ }^{20}$ A pénzügyi szolgáltatási szektor szabályozása, Biztosítási Szemle, 2006. ápr., http://www. biztositas.hu/Hirek-Informaciok/Biztositasi-szemle/2006-aprilis/A-penzugy-szektor-szabalyozasa. html, accessed 16.02. 2016. 
The regulatory policy of the EU was effected by the 2007-2008 financial economic crisis and significant changes have been made, and the events accelerated. The problems are therefore not primarily caused by the crisis, but it served as "a catalyst" 21 . As it has been previously presented, in the vast majority of the Member States there were growing tendencies for unifying the supervisory structures (or supervisors were already operating in an integrated manner before the crisis).

The creation of a supervisory system functioning with similar principles is desirable at EU level too, since the cross-border financial activity between the Member States, the existence of various establishments of parent companies and subsidiaries in different Member States, may create problems in absence of central supervisors who would have proper toolbar and duly overview over these operations. Other important factor is that the role and competence of financial supervisors, the competition rules and consumer culture etc. ${ }^{22}$ differ between the countries, so the monitored environment is not "identical" either.

As a result of the crisis more and more weaknesses and deficiencies of the European supervisory system came to light. Despite the gradual integration of financial markets and the growing role of cross-border institutions, national borders constituted sharp lines for the supervisors concerned. Supervision within the Union functioned on a national basis, which was unable to handle efficiently the financial crisis due to its fragmentation. ${ }^{23}$

In addition, the banking system has undergone significant changes, new bank models have appeared, some financial groups have become more complex, and this requires the supervisory authorities to adapt. basis.

The reform of the financial supervision system has become justified on this

As a first important step, in October 2008 José Manuel Barroso, President of the European Commission at the time, asked Jacques de Larosière ${ }^{24}$ to fill in the presidency of the High Level Expert Group. It was an independent group of eight members that got specific tasks. Three issues needed to be examined:

1. What can be done in terms of supervision of the European financial institutions and markets so that prudential status of financial institutions, proper functioning of markets and the interests of depositors, insured persons and investors be covered in the most efficient manner?

2. How to strengthen European cooperation on financial stability, monitoring, forecasting systems, and crisis management?

${ }^{21}$ Szegedi László: A pénzügyi felügyeletek európai rendszere a Meroni-doktrína tükrében, p. 3, Pro Bono Publico, Támop Speciál, 2011.

${ }^{22}$ Ligeti Sándor: A pénzügyi felügyeletek függetlensége és beszámoltathatósága op. cit. 77.

${ }^{23}$ Jogi Fórum: De Larosiére-jelentés - Megoldási javaslat az európai pénzügyi szabályozás és felügyelés jövőjére, www.jogiforum.hu/hirek/20136, accessed 11.02. 2016.

${ }^{24}$ Former French central bank governor, former member of the Delors Committee, former director of the IMF, former president of the EBRD, G30 member 
3. In what ways could collaborate the European authorities with significant international other states in order to maintain financial stability? ${ }^{25}$

On the whole, they had to develop new concepts determining the future of European financial regulation and supervision. The de Larosière group published its report ${ }^{26}$ following an analysis of the issues on 25 February 2009, which is divided into four main parts and contains 31 recommendations regarding supervision in Europe. The first part deals with the causes of the financial crisis, and the other three parts contain proposals, namely on the political and regulatory actions, the EU supervisory actions and international actions. ${ }^{27}$ The document included short- and medium-term agenda, and clearly delineated community-based structures in the new system. Besides the institutional reform, the creators of the report stressed out the strengthening of the "European supervisory culture", the national legislative revision, the conversion of the sanctioning regimes, and the establishment of colleges of supervisors. ${ }^{28}$

\section{THE NEW SYSTEM IN THE EUROPEAN UNION, THE EUROPEAN SYSTEM OF FINANCIAL SUPERVISION}

Based on the de Larosière report, the European Commission first issued a general communication in 2009 which expressed their support, then published the communication entitled "European Financial Supervision" on a specific plan of action. Following the adoption of the draft legislation the European System of Financial Supervision (ESFS) came to force on 1 January 2011. ${ }^{29}$

The system was built on two levels. The first level consists of macro-prudential supervision, which focuses on the European Systemic Risk Board (ESRC), and comes into being within the European Central Bank and the European System of Central Banks. The duties of the board are analysing the financial markets' significant information on macro-prudential level, and it works as a risk warning system as well, i.e. if risks are detected the ESRC informs the central banks and supervisors, and may suggest specific measures. ${ }^{30}$ Supervisors are obliged to

\footnotetext{
${ }^{25}$ Jogi Fórum: De Larosiére-jelentés - Megoldási javaslat az európai pénzügyi szabályozás és felügyelés jövőjére, ibid.

26 The High-Level Group On Financial Supervision In The EU: De Larosiére Report, 25 February 2009, Brussels, http://ec.europa.eu/internal_market/finances/docs/de larosiere report en.pdf, accessed 16.12. 2016.

${ }^{27}$ Jogi Fórum: De Larosiére-jelentés, ibid.

${ }^{28}$ Forgács Imre: Újabb kihívás a föderális Európának. A Larosiére-csoport jelentése az európai pénzügyi felügyeletről, p. 22-29., Európai Tükör, 2009/4.

${ }^{29}$ Zsolnai Alíz: op.cit. p. 472.

${ }^{30}$ Forgács Imre: ibid.
} 
provide an answer and if they do not comply with the recommendation they shall provide an explanation (this is the so-called: "act or explain" mechanism). ${ }^{31}$

The second level is intended to carry out the micro-prudential supervision, this is the European System of Financial Supervision in the narrow sense. To maintain financial stability with individual institutions as well, the European Supervisory Authorities (ESAs) were set up: the European Banking Authority (EBA), the European Insurance and Occupational Pensions Authority (EIOPA) and the European Securities and Markets Authority (ESMA).

These new authorities replace the 3L3 Committees which are part of the socalled Lamfalussy process, formerly called the Committee of European Banking Supervisors (CEBS), the Committee of European Insurance and Occupational Pensions Supervisors (CEIOPS) and the Committee of European Securities Regulator (CESR). ${ }^{32}$

The micro-prudential "pillar" is supplemented by a joint committee of the ESAs and the national supervisory authorities and the European Central Bank.

To ensure consistent operation of the structure task-sharing and reciprocity are extremely stressful. The ESFS receives micro-prudential information provided by the ESRB, in exchange, gets macro-prudential information, however, these operations do not exclude the bodies' own research and collection of information. ${ }^{33}$ The difference between the two levels is that in the context of EU macro-prudential supervision the ESRB may only adopt decisions in form of soft-law and can also make recommendations, but it does ensure the financial stability of the system, in contrast, in the field of micro-prudential supervision the ESAs can make legally binding decisions in order to deepen the integration process. ${ }^{34}$ Another significant difference is that the ESRB does not have a legal personality, however, the ESAs are separate legal entities. ${ }^{35}$

The system itself is very complex, but in fact it is made up of institutions, which were already existing in some form. The new European Supervisory Authorities are the successors of the aforementioned 3L3 Committees, but, likewise the colleges of supervisors, were already operating before the ESFS. ${ }^{36}$

${ }^{31}$ MNB Jelentése a pénzügyi stabilitásról, Időközi felülvizsgálat, 2009. nov. .

https://www.mnb.hu/letoltes/stabjel-2009-november-hu.pdf, accessed 15.02.2016.

${ }^{32}$ Nagy Zoltán: op.cit. p. 232.

${ }^{33}$ Soós János: Az új európai pénzügyi felügyeleti struktúra, p. 130., Európai Tükör, 2011/2.

${ }^{34}$ Kálmán János: Az Európai Unió pénzügyi felügyeleti rendszerének reformja p. 3., International Relations Quarterly, Vol.5. No.2. 2014/2.

${ }^{35}$ Szegedi László: A pénzügyi felügyeletek európai rendszere a Meroni-doktrína tükrében op.cit. p. 9.

${ }^{36}$ Kreisz Brigitta: A pénzügyi felügyelet igazgatási struktúráinak fejlődése a gazdasági kormányzás megújuló európai koncepciója tükrében, p. 4-5., De iurisprudentia et iure publico, Jog-és Politikatudományi Folyóirat, 2012/3. 


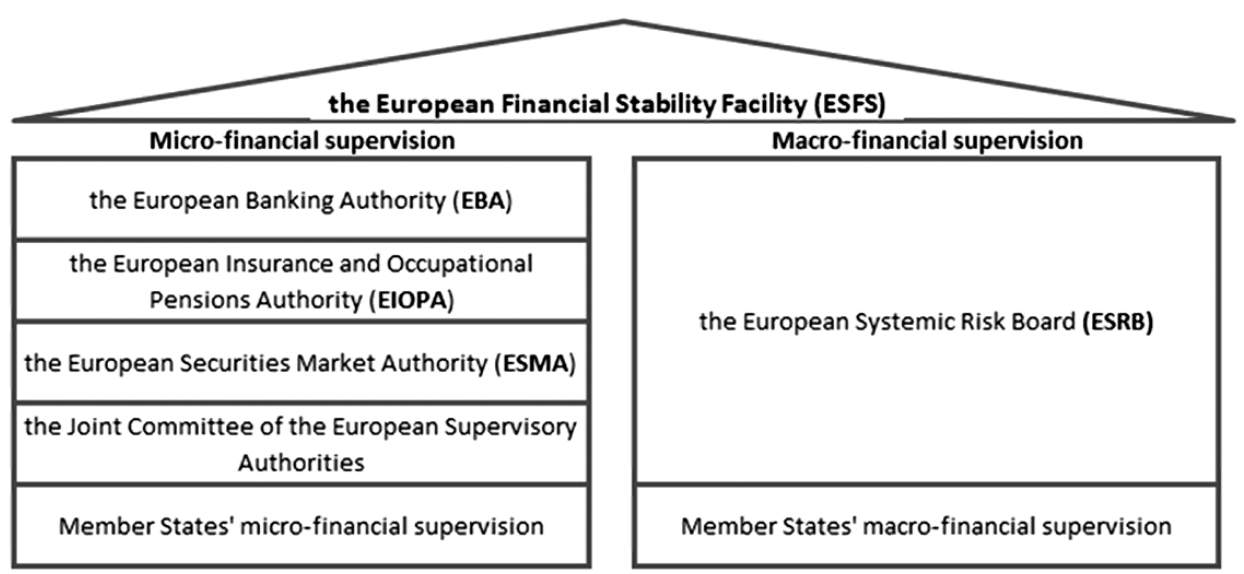

Source: ESRB

The European Systemic Risk Board (ESRB) is responsible for macro-prudential supervision, and does not have a separate legal entity. The main tasks of the ESRB are to prevent risks threatening the stability of the whole financial system, and in a case where they are arisen, identify and analyse them. If necessary, it issues warnings and recommendations. Because of the nature of this corporate body, a number of important EU bodies can be found in its organisation, such as the European Commission, the European Central Bank, national central banks, the European Supervisory Authorities (ESAs), Chair of the Advisory Technical Committee, the Chair and two Vice-Chairs of the Advisory Scientific Committee, and without the right to vote the national supervisors and the President of the Economic and Financial Committee (EFC) ${ }^{37}$. The ECB provides the Board analytical, statistical, administrative and logistical support. ${ }^{38}$ Considering its organisation, there are the General Board, the Steering Committee, Advisory Technical Committee and the Advisory Scientific Committee. The European Union's institutional framework for financial stability is structured around crisis prevention and crisis management in which the ESRB has a key role. ${ }^{39}$

It is interesting to be mentioned that on 29 January 2016 ESRB issued two recommendations that were addressed at national and EU institutions responsible for the implementation of macro-prudential policy. The first recommendation, ESRB/2015/1, concerns the mandate given by the Capital Requirements Directive (CRD) to the ESRB in the area of counter-cyclical buffer rates for banks' exposures to jurisdictions outside the European Economic Area (third countries). It is designed

\footnotetext{
${ }^{37}$ Kreisz Brigitta: ibid.

${ }^{38}$ Európai Központi Bank: Makroprudenciális politika és stabilitás https://www.ecb.europa.eu/ecb/tasks/stability/html/index.hu.html, accessed 16.02. 2016.

${ }^{39}$ Európai Központi Bank: Makroprudenciális politika és stabilitás, ibid.
} 
to ensure that the same counter-cyclical buffer rate for exposures to a particular third country would typically apply across the Union. The second recommendation, ESRB/2015/2, deals with cross-border effects of macro-prudential measures. It sets out the framework for dealing with these cross-border effects and establishes a mechanism for voluntary reciprocity with regard to these measures. It also intended to cover all macro-prudential measures, irrespective of which part of the financial system they address. ${ }^{40}$

\section{THE EUROPEAN SUPERVISORY AUTHORITIES (ESAS OR AUTHORITY)}

The European Supervisory Authorities (ESAs) operate under the same organizational structure. The president is acting on behalf of the body, the Board of Supervisors is the main decision-making body, the Management Board promotes the operations of the organization, in addition, the Joint Committee and the Board of Appeal complete the organization. The members of the Board of Supervisors are the president, who does not have the right to vote, the head of the national authority competent to supervise participants of the financial markets in each Member State, who is at least twice a year personally involved in the supervisory council meeting, one representative of the Commission and one of the ESRB, who are also non-voting. It is also possible to create interest groups within the system. ${ }^{41}$ The ESAs have broad powers, compared to their previous advisory-coordinating function. They can make binding decisions, besides, they are also involved in the legislation by preparing the so-called regulatory and implementing technical standards. The Authority's activities do not affect the daily operation and responsibility of the national supervisors within their areas of competence. ${ }^{42}$

The ESA's competency has five dimensions: ${ }^{43}$

\section{- Responsibilities for cross-border financial service providers}

The dispute settlement mechanism is worth to be highlighted. This means the ESAs' mediation activity, the possibility of a conciliation procedure,

${ }^{40}$ ESRB approves two recommendations that expand the European macroprudential policy framework, Press release of the European Systemic Risk Board, 29 january 2016.

https://www.esrb.europa.eu/news/pr/2016/html/pr160129.en.html ,accessed 17.02. 2016.

41 Regulation (EU) No 1095/2010 of the European Parliament and of the Council of 24 November 2010 establishing a European Supervisory Authority (European Securities and Markets Authority), amending Decision No 716/2009/EC and repealing Commission Decision 2009/77/EC (ESMA REGULATION), Articles 6,37,40.

${ }^{42}$ Kreisz Brigitta: A pénzügyi felügyelet igazgatási struktúráinak fejlődése a gazdasági kormányzás megújuló európai koncepciója tükrében op.cit. p. 6.

${ }^{43}$ Forgács Imre felosztása a Mégsem éjjeliőr? Az európai kormányzás esélyei és a pénzügyi válság c. művében, Osiris Kiadó- Zrínyi Kiadó, Budapest, 2009. In Kreisz Brigitta: op.cit. 
under which the national supervisory authorities can reconcile their disagreements, but only with regard to relevant issues. The process serves a dual purpose. Primarily it is aimed to use in cases where the Member States shall cooperate with each other deriving from an obligation stated in EU rules, for example in joint decision-making, so that a common position can be obtained with the assistance of the Authority. Secondly, this way it is realized indirectly, that the State concerned is required to act by taking into account the interests of the other Member State. The process ends with an agreement, or failing that, with a binding decision.

\section{- Responsibilities for institutions operating on EU level}

Authorization and supervision of, for example, credit rating agencies are included (ESMA)

\section{- Responsibilities for each supervision standards and practices}

E.g. development of recommendations and guidelines

\section{- Responsibilities for the "regulatory area"}

A mechanism should be mentioned here as well, which, in this case, is directed to avoid the Commission's action against a Member State (to prevent regulatory arbitrage). If the authority of a Member State do not applies EU rules properly and any of the Authorities can perceive it in the exercise of the general supervisory powers, then, in the first round, they may make a recommendation, and in exceptional cases, they may take an individual decision.

\section{- Responsibilities for macro-prudential issues}

Cooperation with ESRB related to macro-prudential supervision ${ }^{44}$, which can provide the real risk-based approach of the financial sector. ${ }^{45}$

In order to strengthen the consistency of monitoring results, the ESAs' organize and carry out peer reviews at regular intervals for some or all activities of the competent authorities. ${ }^{46}$ In addition, monitoring and evaluating of market events, and preparing economic analyses are also part of their activity. Moreover, they have consumer protection tasks and perform coordination and oversight of colleges of supervisors.

Their right to take individual decision is the most controversial in the academic literature. Some authors believe that this will ushering them into the same

\footnotetext{
${ }^{44}$ Kreisz Brigitta: A pénzügyi felügyelet igazgatási struktúráinak fejlődése a gazdasági kormányzás megújuló európai koncepciója tükrében op.cit. p. 7-8.

${ }^{45}$ Zsolnai Alíz: op.cit. p. 473.

${ }^{46}$ ESMA Regulation: Article 30.
} 
role which national supervisors have. It is important, however, that there is only limited opportunity to do so under certain conditions. If the national authorities violated EU law and the instruments applying to the institution are directly applicable, the Authority may oblige them to take concrete actions, but only as a last resort. It serves as a "guarantee element" that the Authorities ought to ensure the decision not to conflict with issues related to the budget of the Member States. ${ }^{47}$ Furthermore, it is possible that any natural or legal person bring an appeal against such a decision, including the competent authorities against decisions concerning them directly and individually. The Board of Appeal will decide on the matter, which is a joint body of the three Authorities, whose decision or the decisions taken by the Authorities can be challenged before the Court of Justice of the European Union. ${ }^{48}$

The European Banking Authority (EBA) is based in London. Without prejudice to the EU law, it exercises supervision over individual credit institutions, financial conglomerates, investment firms and payment institutions. ${ }^{49}$ The EBA's duties are monitoring the European banks and the cross-border operations of international credit institutions, promoting cooperation and exchange of information between national supervisors, strengthening European integrity of the supervisory activities, eliminating risks, or in the event of crisis situations enacting the necessary measures. ${ }^{50}$ Where applicable, it may create a Banking Stakeholder Group for effective consultation. ${ }^{51}$

The harmonization of the internal market demands the EBA's significant right to create the so-called Single European Rulebook, which is applicable to all financial institutions in the internal market. ${ }^{52}$

The location of the European Securities and Markets Authority (ESMA) is in Paris. As a special task, this Authority provides the direct European supervision of credit rating agencies. In addition, it ensures proper regulation and supervision of investment and other risks. A Securities and Markets Stakeholder

${ }^{47}$ Szegedi László: A pénzügyi piacok közvetlen európai felügyeletének kihívásai, NKE Egyetemi Folyóirat, Pro Publico Bono, 2011/1.

${ }^{48}$ ESMA Regulation: Article 60.

${ }^{49}$ Regulation (EU) No 1093/2010 of the European Parliament and of the Council of 24 November 2010 establishing a European Supervisory Authority (European Banking Authority), amending Decision No 716/2009/EC and repealing Commission Decision 2009/78/EC (EBA REGULATION), Articles $1,8$.

${ }^{50}$ Tajti Zsuzsanna: A bázeli ajánlások és a tőkemegfelelési direktíva (CRD) formálódása, $p$. 506., Hitelintézeti Szemle, 2011/5.

${ }^{51}$ Soós János: op.cit. p. 134.

${ }^{52}$ Kreisz Brigitta: Az európai bankfelügyeleti hatáskörök válság utáni expanzója - kérdőjelekkel, p. 126., ESMA Rendelet: 1. cikk és 37. cikk Doktori Mühelytanulmányok, Győr, 2014. 
Group has to be established for the purpose of promoting consultation with stakeholders in the affected areas of the ESMA. ${ }^{53}$

The European Insurance and Occupational Pensions Authority (EIOPA) is a Frankfurt-based authority, represented by the President, governed by the Management Board, the main decision-making body is the Board of Supervisors composed of the representatives of national supervisory bodies. ${ }^{54}$ It is responsible for proper regulation and supervision of risk-taking with regard to the insurance, reinsurance and occupational pension activities to foster supervisory convergence and the protection of the insured, policyholders, pension scheme members and beneficiaries. If necessary, an Insurance and Reinsurance- and an Occupational Pensions Stakeholder Group should be set up..$^{55}$

\section{Joint Committee of the European Supervisory Authorities (Joint Committee)}

The Joint Committee is a mixed committee, a forum in which EIOPA cooperates regularly and closely with EBA and ESMA, ensuring the cross-sectoral development of consistency and common positions in the supervision of financial conglomerates. The functions of the President are exercised by the Presidents of the Authorities at intervals of 12 months. The chairman of the Joint Committee is the vice-president of the ESRB at the same time. The Joint Committee has a dedicated staff provided by the Authorities, which allows the creation of an informal exchange of information and common supervisory culture among the authorities. ${ }^{56}$

\section{REGULATION OF THE BANKING UNION}

Following the formation of the European System of Financial Supervision (ESFS) in 2011, they discovered soon that the coordination of the ESRB was not sufficient to prevent the fragmentation of the European financial market ${ }^{57}$ The prudential supervision was still variant in the Member States, which made the deep-

${ }^{53}$ Esma Regulation: Articles 1, 37.

${ }^{54}$ Képviselői Információs Szolgálat: Biztosításfelügyelet, http://www.parlament.hu/documents/10181/303867/2015 39 biztositasfel\%C3\%BCgy/d56f5ae9-855d-4257-b82b-a0d19eb8efe5, accessed 17.02.2016.

${ }^{55}$ Regulation (EU) No 1094/2010 of the European Parliament and of the Council of 24 November 2010 establishing a European Supervisory Authority (European Insurance and Occupational Pensions Authority), amending Decision No 716/2009/EC and repealing Commission Decision 2009/79/EC(EIOPA REGULATION), (10) and (47)

${ }^{56}$ EIOPA Regulation: Articles 2, 54.

${ }^{57}$ Kreisz Brigitta: Az európai bankfelügyeleti hatáskörök válság utáni expanziója - kérdőjelekkel op.cit. p. 117. 
ening of integration more difficult ${ }^{58}$, and implied the risk of a potential crises. ${ }^{59}$ Consequently, further reforms had been made in the organisation. Some EU-level functions of the EBA, as well as some of the Member States' supervisory functions were transferred to the European Central Bank. ${ }^{60}$

The innovation arose as "a political vision" in a statement of the European Commission published in May 2012, and then in the report of the President of the European Council for a "real economic and monetary union". 61

The new financial strategy was the Banking Union that refers to a framework consisting of three pillars. The pillars are: the Single Supervisory Mechanism (SSM), the Single Resolution Mechanism (SRM) and Single Resolution Fund (SRF) and the Deposit Guarantee Schemes (DGS). The single supervisory rulebook (Single Rulebook) completes the system. The implementation of the legislative framework took place in several steps, until today the SSM and the SRM have been carried out.

The Banking Union is based on the Article 114 of the Treaty on the Functioning of the European Union (TFEU) and the Article 127 (6). ${ }^{62}$ The essence of the system is that within the framework of an integrated structure, based on EUwide rules, an EU-wide common banking supervision ${ }^{63}$ operates independently from the Member States in order to prevent a crisis, and if it does happen, the resolution of the institutions involved and the protection of the investments of the depositors are guaranteed. ${ }^{64}$ National supervisory authorities nevertheless are in close cooperation obligations based on strict standards and requirements. The members are all of the current euro area countries, and the countries who adopt euro will become members automatically in the future. The non-euro area countries can join by concluding a so-called close cooperation. ${ }^{65}$

\footnotetext{
${ }^{58}$ Kálmán János: Az Európai Unió pénzügyi felügyeleti rendszerének reformja op.cit. p. 9.

${ }^{59}$ Buda Lorina: Az Európai Unió pénzügyi felügyeleti rendszerének átalakulása és a Bankunió létrehozásának bemutatása, p. 117., Pro publico bono - Magyar közigazgatás: A Nemzeti Közszolgálati Egyetem szakmai folyóirata, 2015/2.

${ }^{60}$ Kreisz Brigitta: Az európai bankfelügyeleti hatáskörök válság utáni expanziója - kérdő-

${ }^{61}$ Kreisz Brigitta: Az európai bankfelügyeleti hatáskörök válság utáni expanziója - kérdő-

${ }^{62}$ Marcel Magnus, Jockum Backman, Cairen Power: Bankunió, 2015/09, p.1.

http://www.europarl.europa.eu/ftu/pdf/hu/FTU 4.2.4.pdf, accessed 02.20.2016.

${ }^{63}$ Az Európai Tanács és az Európai Unió Tanácsa: Szakpolitikák: Bankunió

http://www.consilium.europa.eu/hu/policies/banking-union/, accessed 02.20. 2016.

${ }^{64}$ Buda Lorina: op.cit. p. 118.

${ }^{65}$ Az Európai Tanács és az Európai Unió Tanácsa: Szakpolitikák: Bankunió, ibid.
} jelekkel, ibid. jelekkel op. cit. p. 126. 


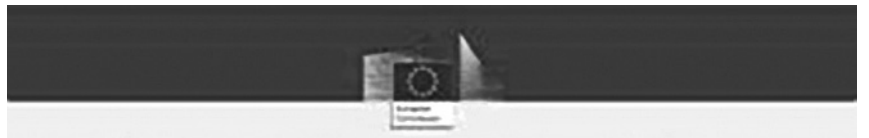

\section{Key elements of the Banking Union}

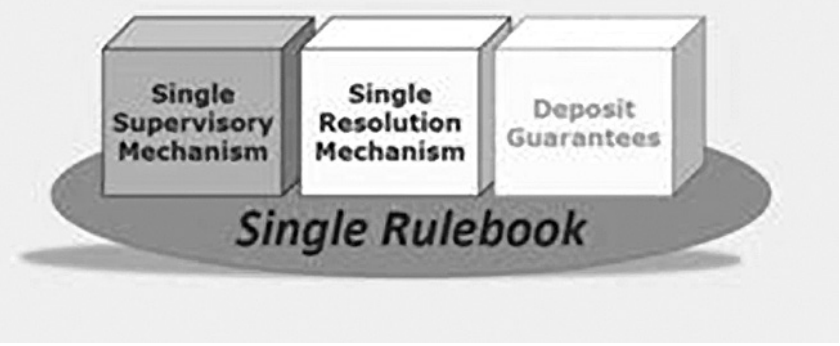

Source: European Commission

The Single Rulebook is made up of regulations, directives and regulatory and implementing technical standards ${ }^{66}$, which apply to all financial institutions in the EU, including approximately 8300 banks and all financial products. For instance, the rules on capital requirements for banks. The EBA is required to ensure effective and consistent implementation of the Single Rulebook in the banking sector. ${ }^{67}$

Three law should be highlighted. The SSM itself was established by the Regulation (EU) No. 1024/2013 conferring specific tasks on the European Central Bank (ECB) concerning policies relating to the prudential supervision of credit institutions and the Regulation (EU) No 1093/2010 establishing a European Supervisory Authority (European Banking Authority) as regards the conferral of specific tasks on the European Central Bank pursuant to Council Regulation (SSM Regulation). The SSM Framework Regulation ${ }^{68}$ sets out the cooperation between the European Central Bank and the national supervisory authorities.

The SSM has been working within the framework of the ECB since 4 November 2014, whereby the ECB's responsibilities were expanded with supervisory powers. According to its report ${ }^{69}$ issued in 30 December 2015, the ECB became

${ }^{66}$ Kálmán János: Az Európai Unió pénzügyi felügyeleti rendszerének reformja op.cit. p. 9.

${ }^{67}$ Az Európai Tanács és az Európai Unió Tanácsa: Szakpolitikák: Bankunió, ibid.

${ }^{68}$ Regulation (EU) No 468/2014 of the European Central Bank of 16 April 2014 establishing the framework for cooperation within the Single Supervisory Mechanism between the European Central Bank and national competent authorities and with national designated authorities

${ }^{69}$ European Central Bank: List of supervised entities, 30 December 2015.

https://www.bankingsupervision.europa.eu/ecb/pub/pdf/list for publishing_20151230en. pdf, accessed 20.02.2016. 
responsible for the direct oversight of more than 130 systemically important financial institutions, however, national supervisory bodies continue to carry out the supervision of other banks under the ultimate responsibility of the ECB. The number of directly supervised banks, of course, can vary over time; and the ECB may decide at any time that a particular bank is a "major bank".70

Before starting the supervisory activity, in autumn of 2014 the ECB made an overall survey, which consisted of an asset quality test and a stress test, in order to the banks' balance sheets be more transparent. ${ }^{71}$ In Hungary, OTP Bank voluntarily undertook the stress test that did not detect the shortage of capital of this credit institution, ${ }^{72}$ but Hungary is not yet part of the SSM.

\section{Countries participating in the Single Supervisory Mechanism}

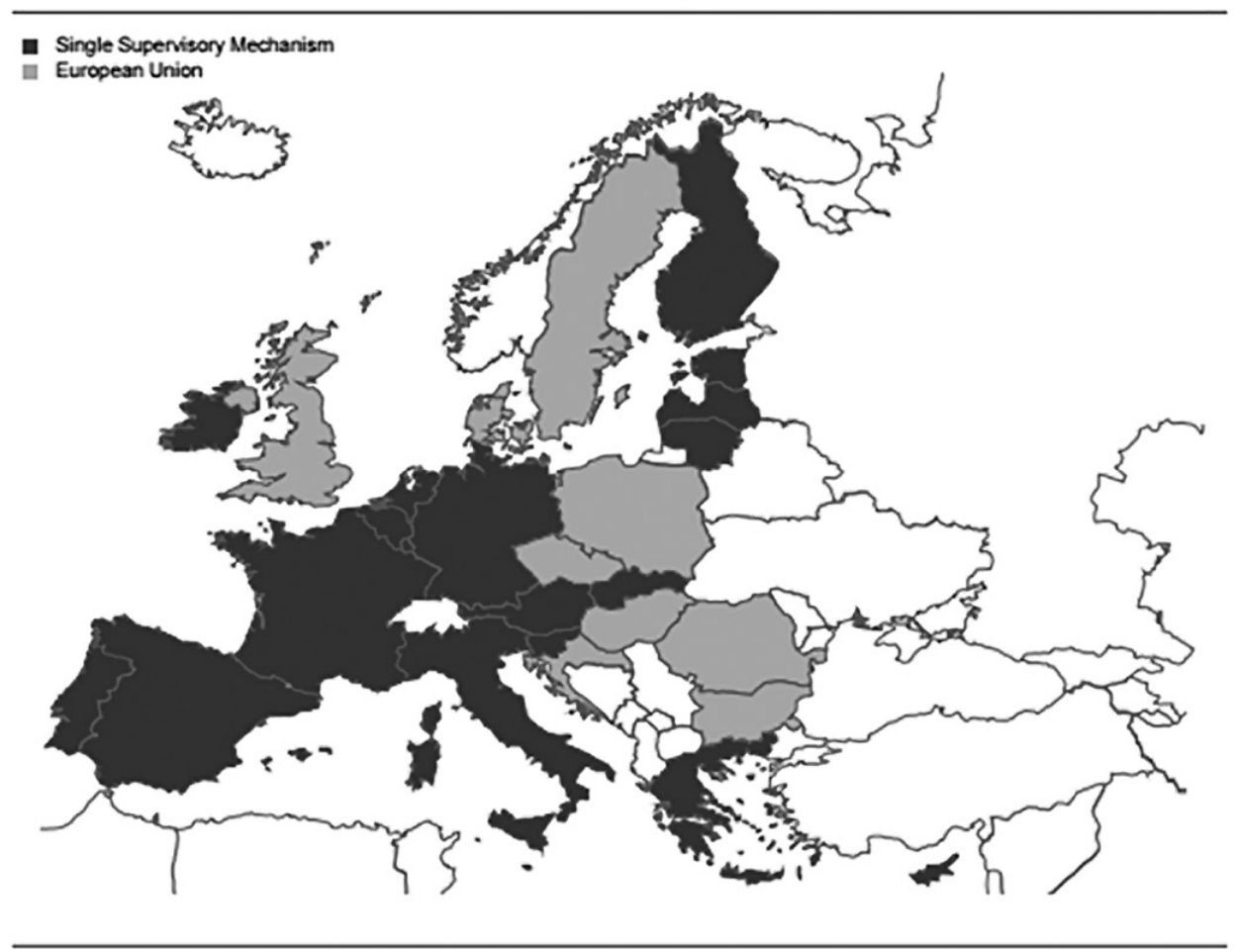

Source: European Central Bank: Banking Supervision: SSM priorities 2016.

The ECB's supervisory tasks are very broad, therefore the listing we make will be non-exhaustive.

\footnotetext{
${ }^{70}$ Marcel Magnus, Jockum Backman, Cairen Power: op.cit. p. 2.

${ }^{71}$ Marcel Magnus, Jockum Backman, Cairen Power: ibid.

${ }^{72}$ Buda Lorina: op.cit. p.120.
} 
There are activities which fall within its exclusive competence, but also performs certain tasks in cooperation with other authorities. Regular checks are made by means of supervision..$^{73}$ In this context, the ECB is competent to control the supervision of smaller banks carried out by the national supervisory authorities, the existence of prudential regulation corresponding to EU rules, and the governance mechanisms within the banks. In addition, it draws up monitoring reports, defines capital buffers and runs stress tests, whereby cooperates with the EBA. It authorizes the operation of credit institutions, where appropriate, it may withdraw the authorization as well. Furthermore, it cooperates mainly with the national supervisory authorities regarding to consumer protection and the fight against money laundering, and with the resolution authority as an "early intervention institution." "I In case of irregularities are discovered during its investigation, penalties may be applied (imposing a fine or penalty payment). ${ }^{75}$ The tools necessary to achieve the supervisory tasks have been set out in a long list in the Article 16 of the Regulation SSM, such a tool is, for example, the requirement of additional or more frequent reporting, or the restriction of operation, network and business of the institutions.

The ECB's supervisory responsibilities are carried out by the Supervisory Board, whose members are the Chair, Vice Chair, four ECB representatives, and representatives of national supervisors of the participating EU Member States. The Governing Council should adopt the complete draft decisions proposed by the Board. The Chair of the Supervisory Board is Danièle Nouy, who was appointed in December 2013, and Sabine Lautenschläger was named as Vice President in February 2014. Both of them have a mandate of five years and is not renewable. The ECB is accountable on the basis of a separate agreement with the European Parliament and the Council. ${ }^{76}$

By establishing SRM the purpose was to enforce a unified approach against the banks close to bankruptcy, by which the stability of the financial sector of the participating Member States might strengthen. A further objective, in addition, was to prevent the crisis spreading to non-participating Member States, which can ultimately ensure the functioning of the internal market. ${ }^{77}$

${ }^{73}$ Az Európai Tanács és az Európai Unió Tanácsa: Szakpolitikák: Egységes felügyeleti mechanizmus http://www.consilium.europa.eu/hu/policies/banking-union/single-supervisory-me$\underline{\text { chanism/, accessed 02.20.2016. }}$

${ }^{74}$ Buda Lorina: op.cit. p. 119.

${ }^{75}$ SSM Regulation (36)

${ }^{76}$ Az Európai Tanács és az Európai Unió Tanácsa: Szakpolitikák: Egységes felügyeleti mechanizmus ibid.

${ }^{77}$ Az Európai Tanács és az Európai Unió Tanácsa: Szakpolitikák: Egységes szanálási mechanizmus http://www.consilium.europa.eu/hu/policies/banking-union/single-resolution-mechanism/, accessed 20.02.2016. 
The legal background is composed of the SRM Regulation ${ }^{78}$ and the RSM Directive ${ }^{79}$.

The SRM began its operations in January 2015, it expands on one hand to the Member States of the euro area, and to the banks joining the Banking Union on the other hand ${ }^{80}$ A more effective resolution mechanism is a basic instrument to avoid damages that arose in the past from insolvency of the banks. ${ }^{81}$

Under Article 3 of the Directive, each Member State shall designate one or, exceptionally, more resolution authorities that are empowered to apply the resolution tools and exercise the resolution powers.

The purpose of SRM is to ensure an efficient resolution of failing banks with minimal costs to taxpayers and to the real economy. ${ }^{82}$ The SRM provides possible plans for resolution without requiring taxpayer bailouts. This can be brought off by the so-called "bail-in" tool, which essentially means that the shareholders and creditors bear the losses. ${ }^{83}$

Besides the above mentioned tool there is another source of financing, the Single Resolution Fund (SRF), a fund established at supranational level. It is available for resolving the failing banks, if other options, such as the recapitalization by creditors and diluting shares (bail-in tool) have been exhausted. ${ }^{84}$ The SRF has been operating since January $2016^{85}$, initially consist of ,national compartments" that will gradually be merged over an 8-year transitional phase so that by 2024 SRF meets the objective, an amount of around $€ 55$ billion. ${ }^{86}$

During the initial build-up phase, a ,,bridge financing” would be used from national sources, consisting of bank levies, or from the European Stability Mech-

${ }^{78}$ Regulation (EU) No 806/2014 of the European Parliament and of the Council of 15 July 2014 establishing uniform rules and a uniform procedure for the resolution of credit institutions and certain investment firms in the framework of a Single Resolution Mechanism and a Single Resolution Fund and amending Regulation (EU) No 1093/201

${ }^{79}$ Directive 2014/59/EU of the European Parliament and of the Council of 15 May 2014 establishing a framework for the recovery and resolution of credit institutions and investment firms and amending Council Directive 82/891/EEC, and Directives 2001/24/EC, 2002/47/EC, 2004/25/EC, 2005/56/EC, 2007/36/EC, 2011/35/EU, 2012/30/EU and 2013/36/EU, and Regulations (EU) No 1093/2010 and (EU) No 648/2012, of the European Parliament and of the Council Text with EEA relevance

${ }^{80}$ Az Európai Tanács és az Európai Unió Tanácsa: Szakpolitikák: Egységes szanálási mechanizmus, ibid.

${ }^{81}$ SRM Regulation (8)

${ }^{82}$ Az Európai Tanács és az Európai Unió Tanácsa: Szakpolitikák: Egységes szanálási mechanizmus, ibid.

${ }^{83}$ Marcel Magnus, Jockum Backman, Cairen Power: op.cit. p. 3.

${ }^{84}$ Az Európai Tanács és az Európai Unió Tanácsa: Szakpolitikák: Egységes szanálási mechanizmus, ibid.

${ }^{85}$ Buda Lorina: ibid.

${ }^{86}$ Marcel Magnus, Jockum Backman, Cairen Power: ibid. 
anism in accordance with existing procedures. The SRF's advantage is that the banks do not depend on any support from the national budget nor the practice of the Member States relating to various financing options. The system will not have significant impact on member states' finances over medium term, because the amounts drawn under the credit lines will have to be repaid by the banks of each country. For the countries not participating in the Banking Union, of course, this will not lead to any cost. ${ }^{87}$

The Single Resolution Board (SRB) is the main body of the mechanism. It has the right to initiate the resolution of a bank, while the decision will be implemented in cooperation with national resolution authorities. The SRB started its work on 1 January 2015, but has been fully operational only since January $2016 .{ }^{88}$ The Board holds either executive or plenary session. The executive session prepares all resolution decisions and strive to adopt decisions that affect banks for which the board is directly responsible. The plenary session is responsible for the more general decisions or above a certain threshold, this meeting will decide on the use of the SRF as well.

The operation of the SRM is a complex process with the collaboration of several bodies. (See the diagram on the next page)

The Deposit Guarantee Scheme (DGS) has so far failed, however, according to the Commission this is the missing third pillar of the Banking Union that could make the banking system a uniformly operating system. Under the current solution for the future is thought to be created a system in which the deposit guarantee funds of the countries would still protect the depositors of all banks up to a maximum of 100 thousand euros, by means of a reinsurance scheme. A new body would be created, the European budgetary council, which would function as a consultant with the participation of five independent experts. Its tasks would be to control the national budgets, to assess how the processes of individual countries affect the euro area as a whole, as well as it may participate in the development of future financial system of the euro area. ${ }^{89}$

${ }^{87}$ Az Európai Tanács és az Európai Unió Tanácsa: Szakpolitikák: Egységes szanálási mechanizmus, ibid.

${ }^{88}$ Marcel Magnus, Jockum Backman, Cairen Power: op.cit. p.2.

${ }^{89}$ Világgazdaság: Új szakaszba lép az eurózóna integrációja, 2015. 10. 22.

http://www.vg.hu/gazdasag/uj-szakaszba-lep-az-eurozona-integracioja-459674, accessed 20.02. 2016 . 


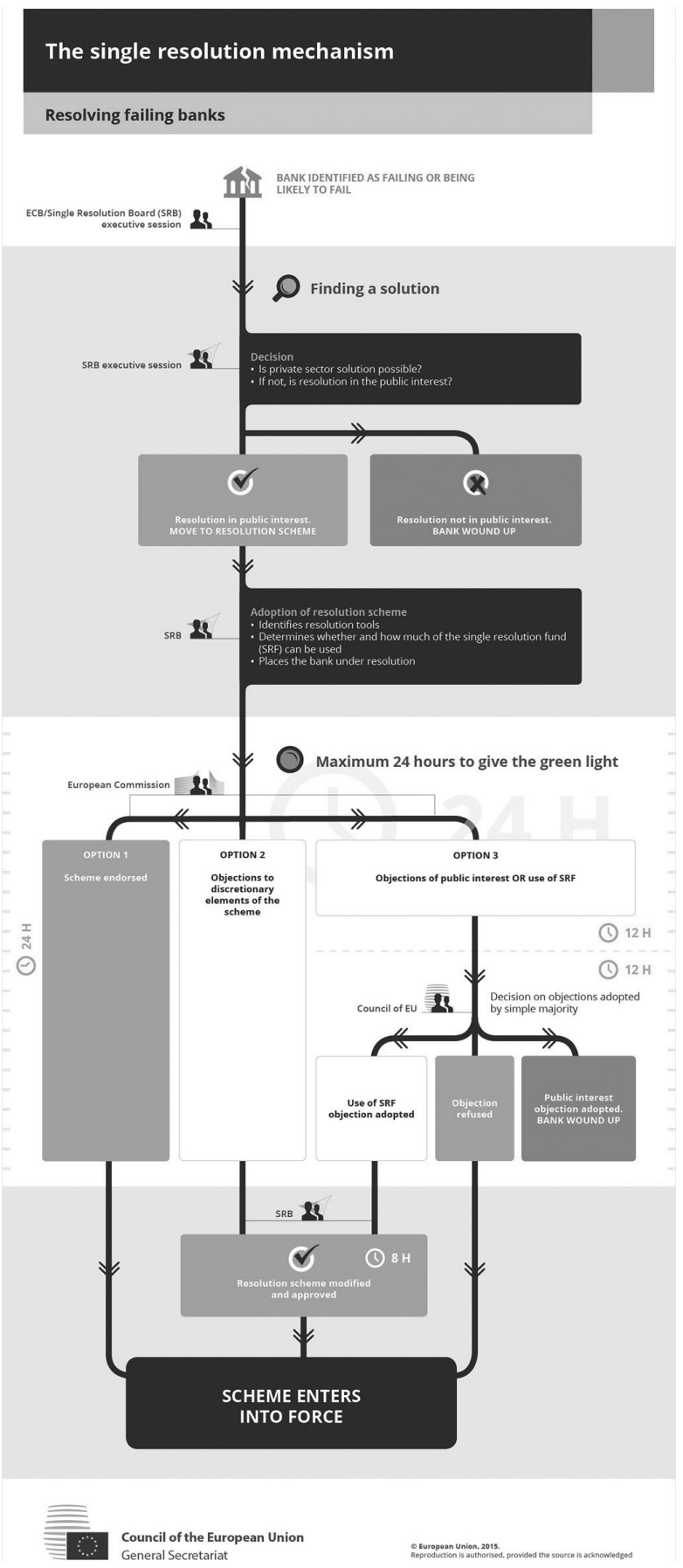


Steps of the operation:

1.The ECB as a supervisor should inform the Single Resolution Board (SRB) if a bank is failing or likely to fail. Such a decision may be taken by the executive session of the SRB on its own initiative, if, after the ECB receives the information does not take steps within 3 days.

2. The executive session shall decide whether it can be solved by private sources or resolution is necessary in the public interest

3. Where the terms of the bailouts are not met, the bank should be wound up in accordance with national law.

4. If the conditions are met for resolution, the SRB adopts a resolution scheme that defines the resolution tools and the use of the Single Resolution Fund. As the SRB adopts the scheme, immediately forwards it to the Commission.

5. The scheme enters into force within 24 hours of the acceptance by the SRB. In the meantime, the Commission shall adopt the scheme, or:

- Object to the discretionary elements of the scheme adopted by the SRB

- Propose to the Council to object to the scheme on the grounds that the resolution cannot be required in the public interest. In this case, the Council shall act by a simple majority.

-Propose to the Council to approve a material modification of the Fund's amount that is provided in the scheme or object to it. Where the Commission intends to propose to the Council to oppose, than it has 12 hours from the approval of the SRB so that the Council is able to decide on within the next 12 hours.

If the Council objects to the resolution of an institution, it will be wounded up under the applicable national law.

6. Finally, the SRB will ensure that the national resolution authorities are concerned to take the necessary measures.

\section{CONCLUSION}

Financial supervision covers a control mechanism, which has demonstrated its necessity and legitimacy particularly due to the financial and economic crisis. The form in which it is realized can be distinct, there are various models. In this regard, a number of authors are trying to collect positive and negative criticisms, arguments and counterarguments.

The fact that the European financial markets undergone a rapid transformation in the last three decades as a result of deregulation and development of information technology, and that financial conglomerates, international financial institutions have emerged and new financial products have evolved, raised doubts about the separate sectoral supervisors and the efficient supervision of the financial markets 
of the various national authorities. The majority of the states committed themselves to the integrated model and the supervision was constructed within the central bank. It is important, though, to develop a structure and regulation in accordance with certain criteria so that the supervisor can actually carry out his duties effectively in an environment where the tasks entrusted to it are off all kinds and different. If not, the path of further development may be extended, or a barrier may be formed as well. ${ }^{90}$

In the European Union efforts for integration have been pervading the regulation policy in the last few years. The European System of Financial Supervision and the Banking Union desire to achieve a truly unified economic and monetary union and to prevent the formation of a new crisis on supranational level through central bodies and mechanisms. Bodies, responsible for the supervision of risks emerging on the level of the individual operators and the system, have been established. However the new system is not fully developed at EU level either. We can encounter objections in connection with the ESAs, and the Banking Union raises many questions as well. (For example, if it is worth it to join as a country like Hungary, which is not a member of the euro area.)

All in all, it can be said that good efforts, a significant progress have been made, the institutional set-up may be able to operate effectively. The crisis has opened up the "window of opportunities" by developing comprehensive reforms..$^{91}$ A supervision that is transparent, responsible, and takes into account the cross-border services, is essential to prevent the formation of a new crisis.

According to experts, the financial supervision was indeed one of the causes of the failure of the financial system, besides to inconsistent regulation and the possibility to make use of the regulatory arbitrage. ${ }^{92}$

${ }^{90}$ Helena Holopainen: Integration of financial supervision, Bank of Finland Research, Discussion Papers, 12/2007 http://www.suomenpankki.fi/en/julkaisut/tutkimukset/keskustelualoitteet/ Documents/0712netti.pdf, accessed 21.02. 2016.

${ }^{91}$ Valia S. G. Babis: Single Rulebook for Prudential Regulation of Banks: Mission Accomplished?, University of Cambridge - Faculty of Law, Legal Studies Research, Paper Series, June 19, 2014. http://ssrn.com/abstract=2456642, accessed 21.02. 2016.

${ }^{92}$ Bilal Hussain: Integrated Financial Supervision and its Implications for Banking Sector Stability, New York University, May 2009

http://www.stern.nyu.edu/sites/default/files/assets/documents/con_043132.pdf, accessed 21.02.2016. 
Др Золиман Б. Нађ, ванредни иррофесор

Универзитеиет у Мищколиу

Правни факулиетеи

jogdrnz@uni-miskolc.hu

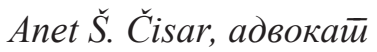

anett.csiszar92@gmail.com

\section{Аспекти европског система финансијске контроле}

Сажейик: У овом раду се размайрају гллавни сйадијуми у развоју регулайиве йосвећене евройској финансијској конйроли, као и акйуелни системе евройске финансијске конйроле. Финансијска криза истиакла је слабостии систиема конитроле, али и чињеницу да она има важну улогуу у зашитийи йойрощача и умањењу ризика финансијских инсиичйуција. Евройска унија развила је нову ситрайег̄ију йознайу као банкарска унија, која йочива на йри стиуба - јединстивеном надзорном механизму, јединстивеном санацијском механизму и заједничкој шеми за осигуурање дейозитиа. Овај систием има за ииль да остивари јединстивену економску и монетарну унију на наднационалном нивоу, као и да избег̄не настианак нове кризе у највећој мог̄ућој мери.

Кључне речи: банкарска унија; финансијска конйрола; SSM; SRM; DGS; Евройска иениирална банка; евройски сисиием финансијске конйроле; банкарска регуулайива.

Датум пријема рада: 05.10.2016. 